Bol. Acad. peru. leng. 52. 2011 (13-38)

\title{
USOS EMBLEMÁTICOS EN EL VIRREINATO DEL PERÚ: ALGUNOS EJEMPLOS EN LA OBRA DE JUAN DE ESPINOSA MEDRANO
}

USAGES EMBLEMÁTIQUES AU VICE-ROYAUTÉ DU PÉROU : QUELQUES EXEMPLES DANS L'OEUVRE DE JUAN DE ESPINOSA MEDRANO

\section{EMBLEMATIC USES IN VICEROYALTY OF PERU: SOME EXAMPLES IN JUAN DE ESPINOSA MEDRANO WORK}

\author{
Julia Sabena \\ Universidad de Rosario
}

\section{Resumen:}

Este artículo da cuenta del impacto y la importancia del modo emblemático de composición y lectura que imperaba en los virreinatos españoles en el Siglo de Oro, particularmente en la obra del cusqueño Juan de Espinosa Medrano. El uso discursivo de los emblemas mantiene contacto con la preponderancia de las imágenes durante el Barroco y aporta matices polémicos, políticos, religiosos, de alabanza o vituperio, según el caso. Para esto se vale de una tradición de relecturas, adiciones y transformaciones que conforman un universo, cuya exploración es necesaria para la atribución de un correcto sentido en gran cantidad de textos áureos. 


\section{Résumé:}

Cet article raconte l'impact et l' importance du modèle emblématique de composition et lecture qui regnait aux vice-royautés espagnols aux siècles d'or, particulièrement dans l'oeuvre du cusqueño Juan de Espinosa Medrano. L'usage discursif des emblèmes garde le contact avec la prépondérance des images pendant le Barroque et apporte des nuances polemiques, politiques, religieux, de louange ou reproche, selon le cas. A cet effet, il se sert d'une tradition de relectures, d' additions et de transformations qui conforment un univers dont l' exploration est necessaire pour l'attribution d'un sens correct en grande quantité de textes d'or.

\section{Abstract:}

This article accounts for the impact and importance of the emblematic use of reading and writing that prevailed in the Spanish viceroyalties in the Golden Ages, specially in the work of the cusqueño Juan de Espinosa Medrano. The discursive use of the emblems relates with the preponderance of images during the Baroque and provides contro versial,religious, praiseful or condemning nuances as appropriate. With this purpose, it uses a tradition of re-readings, additions and changes that make up a universe whose exploration is necessary for the correct attribution of a correct meaning in a great quantity of golden texts.

\section{Palabras clave:}

Espinosa Medrano; emblemas; Virreinato de Perú.

\section{Mots clés:}

Espinosa Medrano; emblèmes; vice-royauté du Pérou.

Key words:

Espinosa Medrano; emblems; Viceroyalty of Peru.

Fecha de recepción: $22 / 10 / 2011$

Fecha de aceptación: $26 / 10 / 2011$ 
https://doi.org/10.46744/bapl.201102.001

El auge de la emblemática en España durante el siglo XVII es bien conocido. Aun cuando el fenómeno sea un avatar del desarrollo de la imprenta ${ }^{1}$, y este no haya sido tan importante o rápido como en otros países de Europa, lo cierto es que para mediados de siglo la cultura estaba repleta de manifestaciones emblemáticas. El placer humanista por las significaciones ocultas y el desciframiento tuvo, si no que ver con su origen, un papel importante en la expansión del hecho. La estrecha relación con el concepto (gracianesco) que en muchas ocasiones representaba un emblema, el modo epigramático del texto, y el uso por parte del Barroco contrarreformista del material iconográfico contribuyeron sin duda a que se convirtiera en una de las lecturas predilectas de los españoles y, por consiguiente, y al tiempo que dejaba de ser material para unos pocos por su popularización, en un vehículo preciado para la comunicación. Como afirman Antonio Bernat Vistarini y John Cull,

Spanish emblematics is preponderantly doctrinal, moralizing, or political $[\ldots]$. And this would continue to be the case in general until the end of the seventeenth century, especially as implemented by the ecclesiastical or sermonistic dimension. Indeed, this focus will bind together all of the other components of Spanish emblematics, from animal symbology or nature in general, to fables, proverbs, and the like (Bernat Vistarini y Cull 1999: 350).

El Virreinato del Perú, parte del imperio español, no se sustrae a este influjo. Además de los libros de emblemas o empresas llegados a las Indias, la práctica emblemática misma (me refiero a la producción e interpretación de emblemas sin necesidad de recogerlos en un volumen temático o unificado) había permeado en la sociedad (al menos en ese círculo menor, poseedor de la cultura humanista). La Ratio Studiorum, a partir de la cual gran parte de la élite se educaba, explicita dentro de su corpus la obligación de componer y descifrar, entre otras cosas, emblemas, empresas, jeroglíficos, que

1 Cf. Antonio Bernat Vistarini y John Cull. 
[convendría] presentarse composiciones de diversos géneros como enigmas hermosamente dibujados con versos al pie y que se regalarían a quien los interpretare. Asimismo epigramas, cartas, discursos, traducciones, emblemas y cuadros a algún autor, figuras de algunos objetos dibujadas con versos como las alas de Teócrito (Bertrán Quera 1984: 307).

No intentaremos hacer un deslinde teórico -que no hallamos en las preceptivas áureas- de cada una de estas formas. Nos interesa, más bien, lo que todas ellas tienen en común: la estructura compositiva, el modo de significar, que se corresponde, en su envés, con un modo de leer. Se ha señalado repetidamente la función didáctica de la literatura emblemática (Bouzy 1993: 36), pero eso no basta. Para escudriñar su excepcional desarrollo también debe unirse, como dijimos, el impulso de la imprenta. Pero además -y creemos que no de manera menos importante- al gusto imperante por la agudeza conceptuosa: "primorosa concordancia, en una armónica correlación entre dos o tres conoscibles extremos, expresada por un acto del entendimiento" (Gracián 1942: 18); por el enigma; por presentarle al lector/vidente un "concepto visual", una cifra que lo asombre, lo fascine, lo induzca al desciframiento y con ello al goce intelectual y fijación en la memoria. Ese placer humanista del que hablábamos más arriba no es solo un pasatiempo, sino que constituye, informa la mirada y la manera de razonar. Encontrar correspondencias y su reverso, desentrañarlas, formaba parte de la actividad de, al menos, la élite letrada.

Parte de esta es, en el Perú, Juan de Espinosa Medrano, el Lunarejo (c. 1629-1688). Poseedor de una amplia biblioteca ${ }^{2}$, inmerso en la cultura humanista y barroca, fue alumno del Colegio de San Antonio Abad, en cuya enseñanza acorde a la Ratio Studiorum habría hecho suya esa capacidad compositiva y hermenéutica que le servirá, dado su mentado poder didáctico, como herramienta en su oratoria, a

2 Cf. Guibovich "El testamento". 
https://doi.org/10.46744/bapl.201102.001

la que incorporará un vasto corpus de emblemas, símbolos, con variada función y desarrollo. ${ }^{3}$

La incorporación de este tipo de recursos a su oratoria le permite transmitir de manera patente el fin propio de cada discurso: en el caso de la oratoria sagrada será la persuasión del auditorio respecto de una lección moral o religiosa, en la celebración de un santo o de un sacramento, etc. En el del Apologético, apoyarán los argumentos tanto de laus (a favor de Góngora, pero también del buen lector y entendedor), como de vituperatio (contra Faria, y contra el lector mal informado) ${ }^{4}$; en la Panegírica declamación, acompañará la finalidad epidíctica, pero sobre todo la deliberativa (cf. Rodríguez Garrido "Defensa del tomismo").

En todos los casos, para que la comunicación entre el autor y el auditorio (o los lectores) se desarrolle exitosamente hay que tener en cuenta dos factores importantes: en primer lugar, el papel del mundo simbólico compartido. El medioevo, el Renacimiento y el Barroco comparten, a pesar de la modernidad de los dos últimos en relación al primero, una mentalidad que no me atrevo a caracterizar como simbólica, pero sí bien dispuesta a ese tipo de lectura o razonamiento. Dice Mujica Pinilla:

el pensamiento barroco está más cerca del mal llamado pensamiento 'pre-lógico' de los 'pueblos primitivos' que de la filosofía positivista de René Descartes. Es más afín al lenguaje sapiencial y colectivo del mito que a la lógica lineal e individualista del racionalismo

3 La razón de esta incorporación (de la emblemática y de la fabulística que, como veremos más adelante, también es recuperada por nuestro autor) la explica Bernat Vistarini, aunque para el caso de Gracián, en argumentos que pueden aplicarse a cualquier orador o escritor de la época: por un lado, la herramienta emblemática o fabulística puede ser objeto de manipulaciones varias y orientadas a distintos intereses (como la propia historia lo muestra y veremos en el desarrollo del trabajo); por el otro, ese tipo de material es conocido por los auditorios o lectores a quienes iba destinado el discurso, razón por la cual éstos pueden "apreciar de inmediato las sugerencias ocultas o secundarias de su empleo" (Bernat Vistarini 2003:360).

4 Para este tema es conveniente el pionero estudio de Eduardo Hopkins Rodríguez "Poética de Juan Espinosa Medrano en el Apologético en favor de D. Luis de Góngora” (1978). 
crítico. [Los símbolos] participan y forman parte de la naturaleza de las cosas manifestando las realidades que representan. Aquí yace el fundamento del arte figurativo cristiano y la clave hermenéutica para leer el mundo natural con vestigia dei o sacramento divino (Mujica Pinilla 2001: 221).

El que el Lunarejo utilice símbolos, emblemas, alegorías, mitología, bestiario tiene que ver con esta disposición o cultura compartida. No siempre reduce el uso de estos elementos a las significaciones ya fijadas por la tradición, sino que en buena parte los resemantiza según sea su interés, como analizaremos más abajo. Y esto nos lleva al otro punto importante, que señala Eduardo Hopkins en "Problemática del receptor", el hecho de que el orador conduce o guía de manera autoritaria el sentido que tendrá la incorporación del recurso emblemático o simbólico:

El constante proceso de comentario o glosa explicativa en torno al corpus utilizado, implica dirigir la recepción del discurso hacia una comprensión predeterminada. El orador no quiere ser malinterpretado, ni que la mente del receptor interprete libremente su exposición doctrinal. La persuasión retórica supone controlar la recepción del discurso (Hopkins Rodríguez 2002: 997).

Así, veremos en algunos ejemplos cómo el hábil y erudito cusqueño maneja diestramente un amplio catálogo de la emblemática (en el sentido más general) que circulaba en su tiempo, adaptándolo según la circunstancia y el interés particular. Sería interminable y estéril, seguramente, un punteo de los innumerables lugares donde cita un emblema o un símbolo, o parte de alguno para ilustrar una idea. Intentaremos, en el desarrollo que sigue, detenernos en algunos pasajes pertenecientes a tres obras distintas y de diferente género y naturaleza, en los que puede verse una apropiación del modo emblemático, donde la emblemática como estructura compositiva o hermenéutica informa activamente el texto y no hace una mera descripción o alusión. 
https://doi.org/10.46744/bapl.201102.001

Un ejemplo del "modo emblemático" de abordar un concepto lo ofrece el desarrollo descriptivo que hace Espinosa Medrano5 en el "Sermón de la Encarnacion del Hijo de Dios" de la insignia de la "salud" que Alejandro Magno le mostró en sueños a Antíoco "le dezia, no dudasse de la victoria, con solo que llevasse la insignia de la salud"6 (EM 1695:42), que no es otra -sabemos- que el pentagrama que los pitagóricos adoptaron como signo identitario: "y en los cinco huecos, que hazen, se figuravan cinco letras, que juntas dezian: Igeya, idest salus" (EM 1695: 42). En un sutil movimiento el Lunarejo troca tal símbolo por el sello del bíblico Salomón:

Eran dos triangulos travados entre si, dos Deltas enlazadas [ya se está refiriendo a la estrella de David, sin advertírnoslo, y ésta sería la pictura], y en los cinco huecos ${ }^{7}$, que hazen, se figuravan cinco letras, que juntas dezian: Igeya, idest salus [...]. Dieron en dezir algunos Rabinos, que no era sino el sello de Salomon, que su incomparable sabiduria hallo, que esta figura de los dos triangulos enlazados era mysteriosa divisa de la salud [inscriptio, mote o lema], fortunado symbolo de la felizidad (EM 1695: 42).

La presentación de un sistema de signos -el simbólico de la insignia- que es descrito y desmantelado por el otro -el lingüístico de la oratoria sagrada:

Como cada triángulo es una Delta, carácter Griego, que significa Naturaleza: Dos Deltas uncidas, que son si no dos naturalezas engazadas en una persona? En esse enlazamiento de dos naturalezas humana, y Divina consistia la salud de el mundo [podría leerse como la suscriptio], Igeya. Mas: que por qualquier angulo que se

5 De aquí en adelante abreviaremos como EM para las referencias bibliográficas.

6 Los cambios consumados en la transcripción a partir de la edición príncipe se limitan a normalizar el uso de "v" y "u", y a cambiar la " $\Gamma$ " por "s".

7 Los dos triángulos trabados conforman la estrella de David o el sello de Salomón, de seis puntas, según la tradición; el que consta de cinco huecos es el Pentagrama. La identificación entre ambos símbolos es paulatina y se atribuye a los místicos medievales (Monreal Casamayor 2004: 33), y está mentada ex profeso confusamente por nuestro autor. 
mira esta divisa, se representa el Arpa Real de su Padre, la Cytara de Maria, y las melodias de Iesus (EM 1695: 42).

De este modo, está orientada a una invención potente destinada a establecer una relación intrínseca o indisoluble, en la mente del auditorio destinatario de la descripción, entre los términos salud y Jesús, encarnación de Dios en hombre. El intento es el de reponer, mediante la identificación de dos signos (uno de origen grecolatino y otro de origen bíblico), la necesidad o la justeza del concepto creado, soslayando la arbitrariedad. Como explica Eduardo Hopkins:

La atribución o imposición de significados adopta la figura de una revelación de significados, como si estos hubieran estado siempre allí esperando que el orador los ponga en exhibición. No se trata sino de una ilusión, pues el orador es quien establece las conexiones de sentido que requiere, por más remotas que fueran (Hopkins Rodríguez 2002: 1101).

Así, la estrella de cinco puntas que para los pitagóricos significara la salud pasa a ser la estrella de seis puntas, absorbiendo el mismo sema del primer signo pero por una cualidad sustancial, inherente a la composición del segundo. Por eso mismo, este se descompone (para cerrar el concepto), gracias al texto, en dos elementos, dos deltas, que cada una significaría una "naturaleza", por lo que la unión de dos naturalezas (la humana y la divina) vendría a ser el Hijo de Dios, la salud del mundo.

\section{Cisne}

En otro caso, también dentro de su obra sermonística, el predicador aprovecha sentidos acumulados por la emblemática para una mayor imbricación y comprensión (siempre orientada al movere) de la idea que quiere transmitir ${ }^{8}$. El énfasis se produce al superponer, en un

8 No siendo este un trabajo acerca de la oratoria sagrada, reduje semejante afirmación al ámbito de la emblemática, aunque es claro que el orador se sirve de todo elemento que pueda ayudarlo en su desarrollo retórico. En la inventio se incorporan personajes mitológi- 
https://doi.org/10.46744/bapl.201102.001

sermón sobre la concepción de la Virgen (en el marco de la iconografía clásica inmaculista), la imagen de un cisne. Rastrearemos brevemente los elementos que confluyen para llegar a tener cabal noción del sentido que el ave pudo aportar: el uso de imágenes en la religión cristiana; el debate en el interior de la Iglesia Católica en relación con la concepción de María y el matiz político particular que adquirió en el virreinato del Perú la iconografía inmaculista.

Luego de un tortuoso periplo, las imágenes religiosas son admitidas durante el Concilio de Trento con fines evangelizadores, vista la enorme capacidad de las mismas para quedar en la mente y memoria del vulgo. Las bases habían sido preparadas cuidadosamente a través de -entre otras cosas- la traducción de San Juan Damasceno, quien ocho siglos antes había defendido el uso de imágenes por la Iglesia católica, aduciendo que los objetos del mundo sensible eran el punto de partida para acceder a las verdades divinas. Las imágenes vuelven a permitirse, dada su funcionalidad para que el pueblo aprendiera los artículos de fe. Esto último es sintetizado por Francisco Pacheco en su Arte de la pintura:

No se puede cabalmente declarar el fruto que de las imagines se recibe. Amaestrando el entendimiento, moviendo la voluntad, refrescando la memoria de las cosas Divinas. Produziendo juntamente en nuestros animos los mayores, i mas eficaces efectos que se pueden sentir de alguna cosa en el mundo. Representandose a nuestros ojos, i a la par imprimiendo en nuestro coraçon actos eroicos, magnanimos, ora de Paciencia, ora de Iusticia, ora de Castidad, Mansedumbre, Misericordia, i desprecio del mundo. De tal manera que en un instante, causa en nosotros desto [deseo] de la virtud, aborrecimiento del vicio: que son los caminos principales que conduzen a la bienaventurança (Pacheco 1649: 142-3).

cos, fábulas e historias paganas, siempre aprovechando el conocimiento que la gente tenía de los mismos con el fin de ilustrar y plasmar en la memoria una lección cristiana. 
A través de ellas, además, se les brindaba debida veneración a Cristo y a su Madre.

La cuestión de la inmaculada concepción de la Virgen María fue también, por su parte, un tema de largas dimensiones. Cuando aún el Concilio de Trento no se afirmaba en una postura, España y sus colonias iniciaron, sobre todo en el siglo XVII, una ofensiva inmaculista para presionar a Roma. En contra de lo que comúnmente se afirma, Suzanne Stratton replica que tal ofensiva no tuvo su origen en el fervor popular, sino que el mismo fue su meta a alcanzar. Las controversias iban y venían y lo único que podía inclinar decisivamente la balanza en favor de la postura inmaculista era que se declarara tradición de la Iglesia, con lo cual adquiriría status de dogma de fe. Si bien se prohibió su discusión en lugares públicos (con lo cual se descartaba la defensa desde el púlpito o en lecturas), la monarquía española, cediendo a los intereses de la Iglesia, lanzó la propaganda para difundir la creencia. Pinturas, esculturas, retablos, poesías, la esparcieron con éxito por todos los rincones hispánicos (cf. Stratton).

La polémica adquirió características propias cruzando el océano. Existía, en el Cuzco, una tradicional rivalidad entre las diferentes órdenes religiosas, signada, seguramente, por un trasfondo de lucha por poderes y privilegios (cf. Guibovich "Como güelfos y gibelinos"). Lo cierto es que esta rivalidad tomaba, en gran parte de los representantes, la forma de discusiones teológicas, como también veremos infra. Tal es el marco en el que se desarrolla la disputa entre maculistas e inmaculistas. El Lunarejo, si bien tomista declarado, en este caso se posiciona como vehemente defensor de la pureza sin manchas de la concepción de María, aun en contra de lo que la orden de Santo Domingo -a la que se encontraba apegado con lazos estrechos- planteaba.

Rodríguez Garrido propone, en una nota de su libro Retórica y tomismo en Espinosa Medrano, que la publicación de las obras de Espinosa Medrano en su tiempo responde a probar la calidad intelectual del Seminario de San Antonio Abad en el Cuzco con miras a ser Universidad. La novena maravilla es el nombre que dieron al compendio póstumo de sermones 
https://doi.org/10.46744/bapl.201102.001

del clérigo cusqueño. La selección, edición y publicación estuvo a cargo de Agustín Cortés de la Cruz, también miembro de la institución antoniana. La elección de los sermones estuvo evidentemente signada por un propósito que ha sido motivo de reflexión últimamente. Las defensas de las posturas tomista e inmaculista se han propuesto como opciones. Mujica Pinilla, por ejemplo, piensa que La novena maravilla pudo haber sido publicada para "dejar atrás toda posible identificación entre el seminario antoniano, y el tomismo antinmaculista” (Mujica Pinilla 2002: 263).

Por su parte, y antes de entrar en el sermón al que nos referimos, conviene recordar algo más. La iconografía inmaculista tuvo una evolución lenta. A lo largo de los siglos se fueron incorporando elementos de fuentes literarias o gráficas a la imagen de la "Misteriosa Muger que vio San Iuan en el cielo" (Pacheco 1649: 482). Francisco Pacheco, en su ya citado Arte de la pintura -recordemos que, al igual que la mayoría de las preceptivas áureas, esta también se escribe a posteriori, en un momento bastante avanzado, por lo tanto prescribiendo usos que ya tenían lugardescribe así la Inmaculada Concepción:

Ase de pintar, pues, en este aseadissimo Misterio esta señora en la flor de su edad de doze a treze años, hermosissima niña, lindos i graves ojos, nariz i boca perfetissima, i rosadas mexillas, los bellissimos cabellos tendidos de color de oro, en fin cuanto fuere possible al umano pinzel [...]. Ase de pintar con tunica blanca, i manto azul; [...]. Vestida del Sol, un Sol ovado de ocre i blanco, que cerque toda la imagen unido dulcemente con el cielo; coronada de estrellas. Doze estrellas compartidas en un circulo claro entre resplandores, sirviendo de punto la sagrada frente, las estrellas sobre unas manchas claras formadas al seco de purissimo blanco, que salga sobre todos los rayos [...]. Una corona Imperial adorne su cabeça, que no cubra las estrellas. Debaxo de los pies la Luna [...]. Adornase con Serafines i con Angeles enteros que tienen algunos de los atributos. El Dragon, enemigo comun, se nos avia olvidado a quien la Virgen quebró la cabeça, triunfando del pecado original [...]. Pero en todo lo dicho tienen licencia los pintores de mejorarse (Pacheco 1649: 482-484, el subrayado es nuestro). 
Es en este marco que se aprecia, entre otras estrategias retóricas, persuasivas y mnemotécnicas, la apelación a la emblemática que hace, como parte de su instrumentación didáctica (y valiéndose de la licencia para 'mejorar'), en la "ORACION PANEGYRICA / A LA CONCEPCION / DE NUESTRA SEÑORA, / EN LA CATEDRAL DEL CUZCO. / Año de 1670", donde hace uso de la densidad semántica del cisne, como anticipamos, para dar mayor realce a su defensa y afirmación de la postura inmaculista:

Mysteriosa constelacion por cierto! Al Cisne se arrima el Sol en aquella Estacion flamante? Pues para què? Para que le preste candidezes, y blancuras: Phoeboque suos cedebar honores. Avia de comproducir el Sol la humanidad mas pura, que hasta entonces avia procreado; no hallò en sus ordinarias luzes decentes instrumentos para tan limpio opificio, y arreòse de todas las blancuras del Cisne, que le prestava mas candor à sus candores, mas pureza à sus claridades: Ibat olor, Phoeboque suos cedebat honores (EM 1695: 52b).

Sus conocimientos astrológicos le permiten saber que la composición de Sagitario, constelación durante la cual habría tenido lugar el nacimiento de María, contiene un cisne, porque "incluso al águila y al cisne los incluyeron también entre las constelaciones en recuerdo de Júpiter, que aparecía así en ciertas fábulas”, dice San Isidoro (2004: 471), y esto le da pie para introducirlo en su discurso.

Pero, además, el cisne tiene una trayectoria emblemática de largo alcance. Si bien en Alciato representa la insignia poetarum (emblema 183), sentido que ha gozado de larga y feliz proyección ${ }^{9}$, ya Diego López en su Declaracion magistral sobre los emblemas de Andres

9 Patente en un sinnúmero de poesías pero, sobre todo, en El cisne de Apolo, libro/emblema apoyado sobre esa relación. Aurora Egido se refiere así a la obra de Alfonso Carballo en su conferencia "La imagen parlante: Emblemática y Literatura áureas" [en línea...]. Y en el mismo Cisne de Apolo: "me pidieron algunos amigos que les declarasse la insignia poetica, que es vn blanco Cisne, en vn escudo pintado, de que haze Alciato vna Emblema, y començando por poco, vine a declaralla con la largueza que en esta obra se contiene, que toda ella no es otra cosa sino declaracio $[n]$ desta insignia" (Carballo 1998: 25). 
https://doi.org/10.46744/bapl.201102.001

Alciato le agrega un sentido escatológico: "Y porque son consagrados à Apolo Dios de los adevinos, cantan tan suave, y dulzemente, quando quieren morir, como adevinando los bienes de la otra vida. Semejante à un Cisne podremos llamar à un santo quando muere, el qual muere contento, porque espera que và à gozar de los bienes de la vida eterna" (López 1670: 624).

Consideramos, no obstante, que Espinosa Medrano se estaría valiendo en este sermón del emblema 8 de la Centuria II de los Emblemas Morales de Sebastián de Covarrubias Horozco (del que, gracias a la publicación del testamento del Lunarejo ${ }^{10}$, conocemos que poseía un ejemplar, junto con un "Andrea Alciati" y uno de Solórzano Pereyra). El emblemista (según se consigna en la Enciclopedia de emblemas españoles ilustrados de Bernat Vistarini y Cull ${ }^{11} \mathrm{y}$, de hecho, el mote es un extracto del libro: elegit contraria flumina flammis) se basa en el libro II de las Metamorfosis de Ovidio, donde Cygno, "qui tibi materno quamvis a sanguine iunctus, / mente tamen, Phaethon" (vv. 368-9) es convertido en cisne a causa de la aflicción que le produce la muerte de Faetón y elige -dice Ovidio- vivir en el agua a causa de odiar el fuego que de manera injusta había enviado Júpiter ("ignemque perosus / quae colat elegit contraria flumina flammis" vv. 379-80), no fiándose ni de este ni del cielo ("nec se caeloque Iovique / credit" vv. 377-378).

En el emblema de Sebastián de Covarrubias Horozco, sin embargo, encontramos una torsión del sentido de este pasaje, que puede apoyarse en traducciones e interpretaciones que sobre la obra de Ovidio circulaban, probablemente, también en el virreinato de Perú. Detengámonos brevemente en ellas.

La primera es, ampliada con creces y propias interpretaciones ${ }^{12}$, la de Jorge de Bustamante, Las transformaciones de Ouidio en lengua española:

10 Cisneros y Guibovich.

11 Pág. 209.

12 De hecho, que sea esta edición la que (o una de las que) llega a manos del clérigo cusqueño aparece como posibilidad si tenemos en cuenta que es la que lee sor Juana (representante 
repartidas en quinze libros, con las Allegorias al fin dellos, y sus figuras, para provecho de los Artifices ([1545]1595). En ella, aun cuando Ovidio habla del "injuste ignis" y del "ignem perosus", el pasaje del epitafio de Faetón se lee de la siguiente manera: "Aquí yaze Faeton governador del carro de su padre: q(ue) porque no lo supo governar, y por aver pedido don a el no conveniente, merescio esta muerte por su grande atrevimiento". (Bustamante 1595: 25, subrayado nuestro), en el que lo injusto cede lugar a lo merecido, a diferencia de la traducción de Sanchez de Viana: "Aqui yaze Phaeton, que governava / El carro de su padre, y si ha caydo / Almenos su osadia fue bien brava" (Sanchez de Viana 1589: 15), donde celebra la audacia y el atrevimiento de Faetón, que Bustamante censura con tono admonitorio.

El mismo autor, en su Libro primero de las Anotaciones de Ovidio, (1589), declara que

La moralidad desta ficcion pone Comité, diziendo, que los antiguos con ella quisieron derribar los brios de los arrogantes y presumptuosos, que les parece que para qualquiera cosa son sufficientes, y piensan que por ser de buena casta lo merecen todo, y a pocos lances se desengañan bien a su costa, sirviendo su cabeça loca de escarmiento para otros q(ue) se cargan a medida de la possibilidad de sus fuerças (Bustamante 1595: 51).

Sabemos que Espinosa Medrano leyó a Natal Comite, según consta en su obra anterior Apologético en favor de don Luis de Góngora, y es muy probable -como dijimos- que conociera la "versión" de Jorge de Bustamante de Las transformaciones. Si bien se estaría basando,

de los círculos cultos americanos), según consta en la Ilustración al sueño, comento epocal que hiciera el poeta canario Álvarez de Lugo Usodemar sobre el poema de la Décima Musa. El comentador descubre en la traducción prolija y "libérrima" (Alatorre 1995:385) de Jorge de Bustamante la causa de que en el Primero sueño se mencione a Almone (vv 93-96), previamente inexistente en la mitología grecolatina, y se refiere al traductor como "anónimo que, con estilo vaxo, infamó el alto estilo de Ovidio, transformando las frases elegantes de sus Transformaciones (traduciéndolas en lengua castellana), dándole a la nimpha que es en Ovidio Nais, este nombre de Almone" (Cruz 2007: 90). 
https://doi.org/10.46744/bapl.201102.001

entonces, en el emblema 8 de la segunda Centuria de los Emblemas Morales de Sebastián de Covarrubias Orozco, cuya subscriptio describe al cisne como "El cierto, y no fingido penitente / [que] Huye, con alas de Christiano Zelo / El fuego, de la culpa, y del pecado, / En las aguas de gracia assegurado". (Sebastián de Covarrubias Orozco 1610: 180. Atiéndase al aspecto didáctico cristiano, externo, es claro, al sentido primero de la fábula), el rasgo que más va a enfatizar en su sermón es el de la bumildad del cisne frente a la soberbia de Faetón, de acuerdo con las interpretaciones que de Ovidio hicieron Natal Comite y Jorge de Bustamante. Retomando la relación que propone en la salutación (Eva es la madre que "tan sobervia por lo gallardo, presumiò emulaciones a lo Divino" [Sebastián de Covarrubias Orozco: 49], haciendo peligrar a María), el cisne, que "al entrar por qualquiera puerta, que por espaciosa, y alta que sea, baxa siempre estudiosamente la cabeça, aunque diste una pica en alto el umbral, receloso de estrellarse la frente en èl, humilla naturalmente el candido cuello" (Sebastián de Covarrubias Orozco: 53) es un "indice hermoso de que no se heredavan en aquel punto los infames erguimientos de Eva; si no que se formava pura el Ave llena de Gracia" (Sebastián de Covarrubias Orozco: 53). El cisne que encuentra en el cielo de Sagitario y presta sus candideces y blancura es presentado como indicio, símbolo, "valiente emblema, de que se producia segunda mejor Eva” (Sebastián de Covarrubias Orozco: 53), prueba de la inmaculada concepción de María. Se valió, en el desarrollo del concepto, del espesor semántico del ave, constituido en parte por la tradición emblemática.

\section{Abejas}

En otro escrito, en principio celebratorio de la llegada del nuevo Corregidor Don Juan de la Cerda y de la Coruña, la "Panegírica declamación por la protección de las ciencias y estudios" (de 1650, según Rodríguez Garrido ${ }^{13}$ ), Espinosa Medrano aparece inserto en la mencionada y notable batalla entre los colegios dominico (San Antonio Abad) y jesuita (San Bernardo) en torno a las enseñanzas de Santo

13 Cf. "La defensa del tomismo por EM en el Cuzco colonial". 
Tomás. Por otro lado, es muy probable -como ya mencionamos más arriba- que las peleas escondieran motivos políticos y de obtención de cargos o privilegios. Podría pensarse, además, que el hecho de que ambas órdenes se disputaran el primer lugar en erudición desde que apareciera la Compañía de Jesús, entraba también como, si no motivo, elemento de pugna, y esto puede vislumbrarse en la "Panegírica declamación". He estudiado en otro lugar la imagen que analizaré más abajo en tanto forma de una autorrepresentación por parte del autor como sujeto altamente letrado y con sobrado entendimiento, quizás como consecuencia del contexto de duda intelectual en el que creían vivir los americanos y frente al cual se posicionaban como la aristocracia humanista de las letras, posición que los emparentaba con sus 'colegas' peninsulares y los desplazaba de binomios poco ventajosos, como español/indiano. En el caso de este escrito, es evidente el trasfondo polémico particular sobre el que el autor afirma su posición. Se ocupará de exaltar no solo su doctitud y su pertenencia al grupo de los 'maiores', sino que además expandirá la red a sus iguales, sus compañeros colegiales antonianos (y "verdaderos" defensores del tomismo), en un movimiento que deslegitima cualquier otra posición. Para esto, planteará un concepto (el tomismo debe ser patrocinado por el corregidor) que desarrollará a partir de un emblema de Alciato pero que se apoyará, además, en significados tópicos que acarrea de largo la abeja: "Y si se apura el discurrir, diré que no cualquier ciencia se inclina al patrocinio de las armas, sino en especial la teología de los tomistas y genuinos discípulos del doctor angélico, y es porque me arrebata ya la pluma el agudo milanés a vuelos de la suya, en un emblema" (EM 1982: 119).

Luego de una bellísima cuanto prolija glosa del emblema (Ex bello pax, donde se ve una celada "acaso olvidada", en el piso, en la que han labrado un panal las abejas), se concentra en la imagen tópica de la abeja y desarrolla parte de su espesura semántica. Ya los antiguos griegos y los latinos cantaban sus virtudes (cf. María Rosa Lida de Malkiel, "La abeja: historia de un motivo poético"). Siempre fue representado como un "insecto sabio" (Lida de Malkiel 1963: 77), laborioso, virtuoso, generalmente en contraste con los áspides o los zánganos, venenosos y holgazanes. Aquí pasa a ser, de la mano de Varrón y Piero (Valeriano) 
"viva imagen de los doctos, noble representación de los estudiosos [...] de las amenísimas selvas que tanto libro forma de sus hojas y de los caudalosos ríos de sabiduría que las inundan, pican vivezas [...]. De que labran bellísimos panales de erudición, a vueltas de la cera, que luciente en sus vigilias liquidó el estudio" (EM 1982: 119).

Siguiendo a San Isidoro de Sevilla, el Lunarejo continúa el desarrollo de su concepto aduciendo que las abejas tienen su origen (o, más astutamente, "derivan su principio de") en los cadáveres de bueyes, pero (Espinosa Medrano hace uso de esta relación, si no original, orientada a sus intereses) no de cualquier buey, aclara, sino de Santo Tomás, a quien sus compañeros de la orden dominica apodaban "el buey mudo de Sicilia". De esta manera los doctos, estudiosos y eruditos, de quienes la abeja es imagen ("doctísimas abejas de Alciato" los llama, presentando el nuevo sentido como inherente al emblema, cuando en verdad no es así, sino que lo incorporó su propio discurso), son los hijos o "genuinos discípulos" de Santo Tomás; excluyendo de esa manera a quienes no lo son, no solo de la legitimidad en materia tomística, sino del resto de las calificaciones y, como consecuencia, por supuesto, del patrocinio de don Juan de la Cerda y la Coruña. "Ese es el buey de cuya silenciosa mudez nacieron doctores tan grandes, o abejas que por el Hybla de la santa teología (al vuelo de sus ingenios) de pimpollos y licores labraron el almíbar de la sabiduría, que partícipes gustamos los verdaderos tomistas a pesar de los adulterinos zánganos que la suavidad le presumen aniquilar" (EM 1982: 121), dice el Lunarejo, en una síntesis a la que llega acomodando y resemantizando el emblema de Alciato hacia sus propios intereses, utilizando, al igual que supra, elementos de la tradición ${ }^{14}$, posicionándose a él mismo y a su comunidad en el lugar más alto de la erudición y de la propiedad

14 La misma figura de las abejas será fructífera en su obra concionatoria. El emblema de Alciato, unido al enigma de Sansón (en la quijada del león muerto también habrían labrado un panal las abejas) le proporciona al autor material para varios sermones: la vida ganaría a la muerte, la dulzura a lo amargo de la hiel; cita también, aunque sin nombrarlo, a Marcial en su epigrama XXXII del libro IV, en donde la abeja muere en su propio néctar, para mostrar el triunfo de la vida y de Cristo (en una resignificación cristiana, claro está), que "anegado en las dulçuras de su piedad, yaze su cadaver vivo entre los mismos nectares, que destila" (EM 1695: 4). 
para tratar la doctrina de Santo Tomás, máxima doctrina de la Iglesia Católica.

En este mismo sentido -el de las resignificaciones-, mencionaremos brevemente otro ejemplo. Para seguir con el bestiario, tenemos que, en La novena maravilla, la relación entre la murena y la serpiente es calificada con un signo positivo o negativo, según la intención persuasiva del autor. Esta operación, si bien para el caso de la perdiz, ya fue notada también por Charles Moore y por Eduardo Hopkins, quien atribuye su punto de partida a la calidad de vacíos (por lo tanto intercambiables y reciclables) que los signos en el Barroco tienen, y a que "En Espinosa, los signos tienen una suerte de condición pre-textual continua, permanente, renovable. El orador es quien determina su textualidad, pero esta se pierde inmediatamente para asumir una nueva textualidad en el discurso" (Hopkins Rodríguez 2002: 1002). En el proceso de significación y resignificación, el Lunarejo no vacila en acudir a su archivo cultural, repleto, como en su ambiente era habitual, de recursos emblemáticos y tradiciones iconográficas de larga data, que nuclean y acumulan varios sentidos, según ya lo vimos en el caso del cisne y de las abejas. Estas últimas, por ejemplo, si "doctísimas" y creadoras en un lugar, en otro "Abeja infausta es la Muerte, que con tragico zumbido de negras alas, ronda los huertos, marchita los Abriles, destroça las flores, fabrica por cera palidez macilenta distila por miel venenos fatales" (EM 1695: 2). $\mathrm{Y}$ en el mismo pasaje la abeja es también Cristo, quien da su vida por los demás; la que se enfrenta a la infausta es la "mystica Abeja, [que] dexandose traspassar de el yugo mato à la Muerte, quebrole el aguijon (...). Matòse por herir la misma muerte, y de la Muerte muerta se hizo un plato de la mesma vida" (EM 1695: 3).

\section{Serpiente y murena}

El emblema 191 de Alciato, "Reverentiam in matrimonio requiri" en principio alecciona acerca del comportamiento respetuoso y de mutua correspondencia en el matrimonio "Mostrando a los casados la manera / Como a de ser el tálamo tratado / Con ánimo de entrambos concertado" (Daza Pinciano, apud Alciato 1993: 235). 
https://doi.org/10.46744/bapl.201102.001

Nuestro autor utiliza esta misma imagen para explicar los preceptos de la eucaristía en la "Oracion Panegyrica al Augustissimo Sacramento". No necesariamente tiene que haberse encontrado con ella en el emblema de Alciato; pero sería ciertamente imposible que la alusión no llevara a pensar en él, tanto a Espinosa Medrano como a su auditorio. "Mas quien os dixera -exclama, eufórico ante la capacidad del mundo natural de emanar significados ocultos-, que en brutas laminas de la Naturaleza dibuxò su soberano Autor symbolos excelentes de aquel Augustissimo Sacramento?" (EM 1695: 1).

De acuerdo con lo recogido por Picinelli en su Mundo simbólico (Alcibiade Lucarini y el mote Deposito jungitur veneno: se une sin veneno; San Basilio amonestando al esposo sobre los deberes morales; San Nilo induciendo a participar todos los días de la eucaristía y San Agustín, probablemente bisagra entre estas imágenes, tomando la unión de estos animales en el sentido cristiano de que el hombre debe deponer malos sentimientos para orar (Picinelli 1999: 170) y de acuerdo, en palabras del Lunarejo, con Bercorio (aunque no hemos podido hallar la cita), va a referirse Cristo como una murena. Esta " $[t]$ iene amistad con la Serpiente [hombre pecador], añudase en amorosos lazos con la Vivora; y es, que la Vivora la llama a silvos desde la orilla, mas para aver de solicitarla, primero dexa el veneno en alguna parte segura, escupe antes toda su ponzoña [confiesa sus culpas]," (EM 1695: 2) y luego de deshacerse de sus pecados por la penitencia y ser "admitida a los abraços de esta Murena, entrañandose con el Cuerpo de Christo en union intima de coraçones, y ayuntamiento estrecho de espiritus por la Sacramental Comunion" (EM 1695:1), el hombre vuelve a sus confesadas culpas. El predicador, sin embargo, persuade para que comulguen durante toda la Octava: "No sea sola una la Comunion, no una la Murena, que de muchas se haze el mas precioso joyel de la Iglesia" (EM 1695: 1). Esto, a su vez, es enlazado con el lugar de las Escrituras -el Cantar de los cantares- en el que el Esposo dice a la Esposa: "Harète Esposa mia, unas Murenitas de oro con esmaltes blancos(...)". Y de esta manera termina, impecable, la Salutación: "Su mejor Pece te ofrece à sus orillas el mar; y pues lo es de Gracias MARIA, no ay sino el pecho al agua, y el coraçon por el arena, saludarla con el Angel, diziendo, Ave gratia plena" (EM 1695: 2). 
No obstante, esa misma imagen animal es valorada de modo opuesto en un sermón cronológicamente anterior, aunque presentado posteriormente en el compendio, la "Oracion Panegyrica à la Concepcion de nuestra Señora”. Aquí, el hecho natural (el libro de la naturaleza) es el mismo: "Vienese la Serpiente à las playas del Mar, silva desde las arenas; la Murena que escucha, sientese reconvenida de la seña, sale cortando espumas al comercio conjugal" (EM 1695: 54). Sin embargo, la lectura del intérprete es otra, amparada o apoyada no ya en el emblema de Alciato, en el que la relación consta de signo positivo, sino en el simbolismo cristiano -del Génesis, pero sobre todo de la iconografía mariana (en la que la Virgen le está aplastando la cabeza)- de la serpiente. Son dos trasluces no solo diferentes, sino, como dijimos, opuestos:

Ya se viene à los ojos [imagen plástica, en relación con esa iconografía] la criminosa infamia de Eva, que essa fue la Murena adultera, que travando comunicación monstruosa con aquel Aspid, le escuchò, y creyo el venenoso silvo, mezclose con la Serpiente [...]. Luego en la Murena se està trasluciendo Eva; su comercio con la Sierpe, el fomes de la culpa, el silvo mortifero (EM 1695: 54).

A nadie se le hubiera ocurrido, sin embargo, sorprenderse por esto, dada la intercambiabilidad o movilidad de sentido de los signos y la dilogía, tan propia de la palabra barroca, que impregna los discursos.

\section{Envidiosos y maldicientes}

Para terminar, consignaremos un último pasaje, en el que se produce una fusión o encadenamiento de sentidos entre emblemas, que lleva a una composición clara de lo que el -en este caso- polemista quiere declarar. El Lunarejo principia el Apologético en favor de don Luis de Góngora (donde discute al "caballero portugués Manuel de Faria y Sousa" sus encendidas acusaciones contra el poeta cordobés) con el emblema 144 de Alciato, Inanisimpetus, en el que el perro le ladra a la luna, "pero sordo a tan importunas voces prosigue el cándido planeta el volante lucimiento de sus rayos" (EM 2005: 131). Si bien los comentaristas (Diego López, el Brocense) coinciden en señalar este emblema como parte de su diatriba 
https://doi.org/10.46744/bapl.201102.001

contra los maldicientes, los murmuradores, a quienes conviene desoír sin prestar atención (tal la actitud de Diana ante los ladridos del perro), Espinosa Medrano parte de él para tratar el cercano tema de la envidia. Aunque esta tiene su representación emblemática quizás más famosa en Alciato, imagen proveniente de las Metamorfosis (vv. 768-782) y con extensísima proyección en las letras, ambas formas (la de la envidia y la de los murmuradores) están íntimamente conectadas ya que, como reza el Tesoro de la lengua castellana de Covarrubias, la murmuración es "una plática nacida de la envidia, que procura manchar y obscurecer la vida y virtud ajena", conexión que regirá las páginas siguientes y que Espinosa Medrano se encargará de estrechar.

En esta relación, Góngora sería la luna ("Luna fue esplendidísima el insigne y raro poeta cordobés Don Luis de Góngora" [EM 2005: 132]) ladrada y mordida por Faria, el perro ("No sé qué furia se apoderó de Manuel de Faria y Sousa, para que de comentador de Camoens se pasase a ladrador de Góngora" [EM 2005: 132]). En el parágrafo siguiente, continuando el vituperio pero sin mencionar emblema alguno, Espinosa Medrano se despacha con esta frase aguda y sentenciosa: "morder para pulir, beneficio es de lima; morder por solo roer, hazaña será de perro" [EM 2005: 132]. Tenemos, subyacente, el emblema 12 de la primera Centuria de Sebastián de Covarrubias: Carpit et carpitur una, que se refiere específicamente a la envidia (el mote es un extracto del verso 781 de las Metamorfosis) que, sin embargo, le sirve a nuestro autor para enfatizar la esterilidad del maldiciente o murmurador, del perro que, según nos presentó más arriba, ladra por la percepción errónea de un reflejo, semejante a la fábula esópica en la que el can pierde su alimento por perseguir el de su imagen especular, inexistente. No es tanto el "morder" lo que está en cuestión, sino el sinsentido, la pérdida de tiempo y el esfuerzo vano, porque lo que triunfa (Cisneros nos recuerda que estamos frente a un sacerdote) es la verdad ${ }^{15}$. La erudición misma

15 "Nótese -dice Hopkins- que Espinosa Medrano no contrapone a la envidia la caridad, que es lo usual en el plano sapiencial, sino la verdad. La verdad sobre la poesía de Góngora es uno de sus objetivos [...]. La envidia es injusta, falsifica la verdad o la niega(...)" (Hopkins Rodríguez 2007: 532). 
puede ser mordaz, "pisada de grosero pie [...] áspid que espeluce las escamas, que muña el silvo, que vibre la lengua, que clave los colmillos y torne los antídotos en venenos" (EM 2005: 217), si es para defender a la verdad. En efecto, es justamente lo que el ingenio sutil de Espinosa Medrano lleva a cabo sin piedad a lo largo del Apologético. Su propósito declarado es que "salga a luz esta iniquidad, examínese el dictamen y desengáñese el mundo" (EM 2005: 134); “[a Góngora] no lo juzgue la envidia, censúrelo la verdad” (EM 2005: 216). Frente a ella, y acudiendo a otra de las imágenes canónicas del vicio, las falsedades que nacen de la envidia: "La hacha de Hércules en los cuellos de la Hidra se echará menos al confutar el error de Faria, de que tantas falsedades porfiadamente brotan" (EM 2005: 150).

Vimos entonces, a lo largo de varios ejemplos, el uso que del género emblemático hizo Juan Espinosa Medrano, erudito sacerdote perteneciente al núcleo letrado de la sociedad cusqueña del siglo XVII. El grado de apropiación y adaptación al discurso es una muestra de cuán hondo había calado la emblemática en la sociedad virreinal, informando -como decíamos al principio- el modo de razonar y expresarse. Los ejemplos podrían multiplicarse, pero valgan los ofrecidos como muestra de la estructura compositiva de la que participaban, cristianizando, resignificando, fusionando sentidos, produciendo deleite y funcionando como factor mnemotécnico: formando parte inseparable del constructo cultural barroco americano del siglo XVII. Sobre todo en la obra sermonística se manifiesta la utilización del emblema como parte de la tendencia generalizada a las imágenes en el seno de la cultura hispánica; emerge la función didáctica de la enseñanza moral mediante una forma intuitiva que, sumando la tendencia enigmática e ingeniosa-compartida con el concepto-, cumple con el objetivo de todo escritor barroco: sorprender y mover al público. 
Usos emblemáticos en el VirReinato del Perú: Algunos ejemplos...

https://doi.org/10.46744/bapl.201102.001

\section{BIBLIOGRAFÍA}

La Santa Biblia. Antiguo y nuevo testamento. Versión de Casiodoro de Reina. Londres: Sociedades Bíblicas Unidas, 1960.

ALATORRE, Antonio. "Notas al Primero sueño de sor Juana". Nueva revista de filología hispánica, n. ${ }^{\circ}$ 43, 2, 1995, pp. 379-407.

ALCIATO, Andrea. Emblemas. Madrid: Akal, 1993.

AlCIATO, Andrea. Emblemata. Padua: Petro Paulo Tozzi, 1621. http://www.emblems.arts.gla.ac.uk/alciato/books. php?id=A21a. Lunes, 9 de agosto de 2010.

BERNAT VISTARINI, Antonio. "Del bestiario y las imágenes zoomórficas en la obra de Baltasar Gracián” en Baltasar Gracián IV Centenario (1601-2001). Actas I Congreso Internacional "Baltasar Gracián". Zaragoza, 2003.

y John Cull. Enciclopedia de emblemas españoles ilustrados. Madrid: Akal, 1999.

BERTRÁN QUERA, Miguel. "La pedagogía de los jesuitas en la Ratio Studiorum". Paramillon, n. ${ }^{\circ} 2-3,1984$, pp. 2-540.

BOUZY, Christian. "El emblema: un nuevo lugar estético para los antiguos lugares éticos". Criticón, n. ${ }^{\circ}$ 59, 1993, pp. 35-45.

BUSTAMANTE, Jorge. Las transformaciones de Ouidio en lengua española: repartidas en quinze libros, con las Allegorias al fin dellos, y sus figuras, para provecho de los Artifices. Amberes: Pedro Bellero, 1595.

CARBALLO, Luis Alfonso de. Cisne de Apolo. Edición de Alberto Porqueras Mayo. Madrid: CSIC, 1958. 
https://doi.org/10.46744/bapl.201102.001

COVARRUBIAS OROZCO, Sebastián de. Emblemas morales. Madrid: Luis Sánchez, 1610.

Tesoro de la lengua castellana o española. Edición integral e ilustrada de Ignacio Arellano y Rafael Zafra. Madrid: Studiolum, 2006.

CRUZ, sor Juana Inés de la. Primero sueño. Edición del texto y notas de Tadeo P. Stein. Rosario: Serapis, 2007.

EGIDO, Aurora. Conferencia: "La imagen parlante: Emblemática y Literatura áureas" http://www.march.es/Conferencias/ anteriores/voz.asp?id $=188$. Viernes 5 de marzo de 2010.

ESPINOSA MEDRANO, Juan de. La novena maravilla / nuebamente ballada en / los Panegiricos sagrados qen varias Festividades di / xo el Sor. Arcediano Dor. D. Iuan de Espinosa / Medrano primer Canonigo Magistral Tesorero Chan / tre y finalmente Arcediano de la Cathedral del Cuzco en los Reynos / del Piru. Valladolid: Joseph de Rueda, 1695.

. Apologético. Selección, prólogo y cronología por Augusto Tamayo Vargas. Caracas: Biblioteca Ayacucho, 1982.

- Apologético en favor de Don Luis de Góngora. Edición anotada de Luis Jaime Cisneros. Lima: Universidad de San Martín de Porres, 2005.

GRACIÁN, Baltasar. Agudeza y arte de ingenio. Buenos Aires: Espasa Calpe, 1942.

GUIBOVICH PÉREZ, Pedro. "Como güelfos y gibelinos: los Colegios de San Bernardo y San Antonio Abad en el Cuzco durante el siglo XVII". Revista de Indias, n. ${ }^{\circ}$ LXVI, 2006, pp. 107132. 
https://doi.org/10.46744/bapl.201102.001

. "El testamento e inventario de bienes de Espinosa Medrano". Histórica, n. ${ }^{\circ}$ 16, 1992, pp. 1-31.

HOPKINS RODRÍGUEZ, Eduardo. "Poética de Juan de Espinosa Medrano en el Apologético en favor de D. Luis de Góngora". Revista de Crítica Literaria Latinoamericana, año IV, n. ${ }^{\circ} 7 / 8$, 1978, pp.105-118.

- "Problemática del receptor en Juan de Espinosa Medrano". En Eduardo Hopkins (editor): Homenaje a Luis Jaime Cisneros. Lima, Fondo Editorial PUCP, 2002, pp. 973-1007.

- "Recusación de la envidia en el Apologético en favor de don Luis de Góngora, de Juan de Espinosa Medrano". En Enrique Ballón (coordinador): Simulacros de la fantasía. Nuevas indagaciones sobre arte y literatura virreinales. México: UNAM, 2007, pp. 523-534.

ISIDORO DE SEVILLA, San. Etimologías. Madrid: BAC, 2004.

LIDA DE MALKIEL, María Rosa. "La abeja: historia de un motivo poético". Romance Philology, n. ${ }^{\circ} 17: 1,1963$, pp. 75-85.

LÓPEZ, Diego. Declaracion / magistral / sobre las emblemas / de Andres Alciato. I Con todas las historias, / antigüedades, moralidad, $y$ / doctrina, tocante a las / buenas costumbres. Valencia: Geronimo Vilagrase, 1670.

MONREAL CASAMAYOR, Manuel. "De sermone heráldico IV: astros y meteoros". Emblemata, n. ${ }^{\circ} 10,2004$, pp. 209-261.

MUJICA PINILLA, Ramón. "El arte y los sermones". El barroco peruano. Lima: Banco de Crédito del Perú, 2002, pp. 219-323.

- "Humanismo y escatología en el Barroco Peruano: aproximaciones a la mentalidad simbólica". José Pascual 
https://doi.org/10.46744/bapl.201102.001

Buxó, editor. La producción simbólica en la América colonial. México: UNAM, 2001, pp. 221-236.

OVIDIO. P. Ovidi Nasonis Metamorphosen liber secundvs. http://www. thelatinlibrary.com/ovid/ovid.met2.shtml. Viernes 20 de agosto de 2010.

PACHECO, Francisco. Arte / de la pintura, / su antigüedad / y grandezas. Sevilla: Simon Fajardo, 1649.

PICINELLI, Filippo. El mundo simbólico. Serpientes y animales venenosos. Los insectos. Michoacán: El Colegio de Michoacán, 1999.

RODRÍGUEZ GARRIDO, José Antonio. "La defensa del tomismo por Espinosa Medrano en Cuzco colonial". Sonia V. Rose, Karl Kohut, editores. Pensamiento europeo y cultura colonial. Frankfurt, Vervuert; Madrid: Iberoamericana, 1997, pp. 115-136.

. Retórica y tomismo en Espinosa Medrano. Lima: PUCPIRA, 1994.

SÁNCHEZ DE VIANA, Pedro. Las transforma / ciones de Ovidio: Traduzidas del / verso Latino, en tercetos; y octavas / rimas, Por el Licenciado Viana. Valladolid: Diego Fernández de Cordova, 1589.

STRATTON, Suzanne. La Inmaculada Concepción en el arte español. Traducción de José L. Checa Cremades Cuadernos de arte e iconografía, n. ${ }^{\circ}$ I-2, Fundación Universitaria Española, 1988 .

\section{Correspondencia:}

Julia Sabena

Docente de la Universidad Nacional de Rosario (Argentina). 